\title{
A Comparative Analytical Study of Some External Finishing (Cladding) Material in Terms of Their Ability to Spread Fire in Multi-story Building Facades in Iraq
}

\author{
Ahmed A. Alfakhry \\ Architectural Department, College of Engineering, University of Mosul, Mosul 41002, Iraq
}

Corresponding Author Email: ahmed.alfakhry@uomosul.edu.iq

https://doi.org/10.18280/ijsse.100509

Received: 8 July 2020

Accepted: 12 October 2020

\section{Keywords:}

external facades, fire propagation, computer simulation, external finishing and cladding materials

\begin{abstract}
The traditional building in Iraq characterised by the using of a certain number of finishing's in external façades like cement plastering, limestone and perforated yellow brick because the raw materials of manufacturing are available locally. Fire spread through the facades is widely recognized as one of the fastest pathways of fire spreading in the buildings, so the appropriate choose of highly performance finishing material against fire will be potentially the main factor in controlling the fire and suppressed it. This study uses computer modeling and fire simulation technology of Pyrosim, FDS and smoke view to compare the difference between the performance of some traditional finishing materials like cement plastering, limestone and perforated yellow brick with the ACPs and their speed to transfer fire from floor to floor if used in multi storey buildings. The study highlighted that traditional finishing materials are more efficient than modern cladding materials and that the performance of ACP-PE is the worst among the materials examined by this study. Moreover, the cement plastering is the worst among the traditional local finishing materials.
\end{abstract}

\section{INTRODUCTION}

Spreading fire through the façades (The word façade in this research refers to any face of a building (the front view or elevation) given special architectural treatment, that faces on to a street or open space.) is widely known as one of the fastest pathways of fire spreading in the buildings. The spreading of fire through the façade follows various ways, which depending on the type of façade system, elements, and construction materials.

In multi-story building façades, fire may spread along the following routes:

(1). Through the window openings by the so-called "leapfrog" effect (The term leapfrog effect of fire according to ASTM refers to the ability of a flame to spread from one floor to the next around the building's perimeter containment system. This means that the fire will propagate out a window in the fire's room of origin and crawl up the side of the building.).

(2). Through the external finishing material or the cladding surfaces, when the reaction of the material to fire contributes to the rate of fire spread.

The traditional building in Iraq is characterized by using a certain number of finishing's in external façades, such as cement plastering, limestone, and perforated yellow brick. Last few years, the Iraqi construction market has witnessed the entry of new finishing materials used as cladding, especially in multi-story building facades, one of these new cladding materials is the Aluminum Composite panels. These finishing materials differ in their performance of fire spreading in through the building facades. This study aims to compare the fire performance of each of these finishing materials and their speed to transfer the fire to other floors when it used in multistory buildings.

\section{THE FINISHING MATERIALS}

\subsection{Perforated yellow brick}

Perforated yellow brick is a clay material treated with high temperatures. Nowadays, it is made of four-sided polishing faces while it was previously rough and non-perforated, cut and formed using saws. Used to finish building facades and is currently manufactured with penetrating holes of more than $25 \%$ of the brick size, and has Standard dimensions of $23 \mathrm{x}$ $11.5 \times 7.5 \mathrm{~cm}$ [1]. The yellow brick is the first building construction material in central and southern regions of Iraq, where the nature of sedimentary soils helps in manufacturing it. The fact of competitive alternatives is currently unable to compensate for its use widely for several reasons, including the availability of raw materials for alternatives [2].

\subsection{Limestone}

Limestone is a sedimentary rock that contains mainly calcium carbonate with a small percentage of sand or clay materials and iron oxide. These stones are often easy to cut and shape, but some are hard to shape. Limestone is efficient for construction, which widely used in Iraq.

The average thickness of stones that used as cladding are 50 and $120 \mathrm{~mm}$, and chicken wire used to connect the pieces of the stone to the structure wall in addition to the cement-sand mortar [2]. 


\subsection{Cement plastering}

It is the most common finishing type in Iraq which consist of one or two layers, the first being a thickness of at least 15 $\mathrm{mm}$ in the walls and maybe less than that in the ceilings, while the second layer is about $4 \mathrm{~mm}$ thick. The work of the final surface is either parallel to the face of the wall, i.e. making the thickness of the finishing almost constant and may leave the face rough to receive another finish layer or polish directly, and the thickness, in this case, is about $20 \mathrm{~mm}$ [2].

\subsection{Aluminum composite panels}

ACP panels are essentially composite panels, which consist of a core material sandwiched between two thin layers of Aluminum (or other metal) sheets. The thickness of the Aluminum is usually on the order of $(0.5 \mathrm{~mm})$, the total thickness of the Aluminum facers covered with durable and weather-resistant coatings [3].

The core material of the ACP panel usually defines its combustibility. There are three types of ACP cladding: ACP with polyethylene dominated core referred to "ACM-PE" (100\% combustible); fire retardant ACP cladding with a better fire performance referred to as "ACP-FR" (70\% noncombustible mineral fill added to the combustible thermoplastic core); and ACP cladding with a mineral core filling of limited combustibility referred to as "ACP-A2" (90\% mineral fill added to the combustible core) $[3,4]$.

The ACP assemblies can be installed on new and existing building facades to improve energy efficiency, weatherability (air /moisture), and aesthetics. Although ACP assemblies are used in internal wall and roofing systems. The primary application is in the external wall systems [4].

The cladding used a joint system for installation, such as brackets, channels, or other attachment systems to the substrate, thereby creating an air cavity directly behind the cladding. The air cavity allows the rainwater to drain down the building. The upward airflow within the cavity during hot weather facilitates removal of any remnant moisture, thereby keeping the façade ventilated. The air cavity thickness behind the cladding is typically ( 25 to $100 \mathrm{~mm}$ ). In a fire case, both external flame spread on the cladding and internal cavity fire spread can cause vertical flame propagation on a building façade [4].

In Iraq is the Aluminum Composite Panels with combustible polyethylene core (ACP-PE) used widely because of cheap expensive, which caused many fires in most Iraqi cities as well as around the world.

Nowadays, these materials are the essential elements that form the majority of commercial and residential buildings facades in Iraq.

\section{RELATED STUDIES}

Studies related to limit the risk of spreading fire through multi-story building facades can be in the main three categories:

(1) Through the design and geometry of the facade: To use construction elements capable to avoid the contact between the fire plume and the combustible cladding. Providing deflector elements with the ability to change the trajectory of the flames and prevent its passage into other compartments [5-7].
(2) Through the use of the certain type of flame retardant treated cladding and non-combustible finishing building materials $[3-5,8]$.

(3) Through the choice of the most appropriate fire performances building external wall insulation materials which improves the façade's thermal behavior and avoids the appearance of moisture from rain or condensation and act as a part of the cladding system. or through the control of cavity size in the ventilated facades system $[9,10]$.

The methodology of the three categories of previous studies was conducted on either:

- Numerical approach.

- Experimental approach, the large, the medium or the small scale fire tests or:

- Computer simulation through advanced CFD software, such as FDS, Pathfinder, or Simtec.

This study is classified under the third category and based on computer simulation.

\section{OBJECTIVE}

The study aims to compare the performance of Aluminum Composite Panels (ACP-PE) that used as cladding in building facades in case of fire propagation and speed to transfer the fire to upper stories, with the performance of some traditional finishing materials, such as Cement plastering, Limestone and Perforated Yellow Bricks under the same circumstances.

\section{METHODOLOGY}

The current study used field models of computational fluid dynamics to compare the fire performance of some finishing and cladding materials through external building facades using Fire Dynamics Simulator (FDS version 6.4) [11]. To solve the models, PyroSim for the graphical interface, and Smokeview to visualise the results.

One of the significant advantages of Computer simulation is the possibility to study some aspects of the phenomenon of fire without incurring the high costs of laboratory tests, which does not mean that computer-simulation can replace the laboratory tests. However, it is a powerful tool for carrying out complementary studies, mainly as regards the physical behavior of fire [9].

This research has made a scenario representing fire in the living room of an apartment. Once the fire reaches the stage of flashover, the fire spreads to outside through the windows. The models show a simplified representation of analysed cases.

Four cases have been evaluated based on a computational domain created and a fire scenario. The study conducts a comparative method of fire spread through four common materials used as external finishing or cladding through building façade in Iraq.

\section{COMPUTATIONAL DOMAIN}

In a computational fluid dynamic, a smaller grid size (more number of cells) provides more accurate results but needs more time for calculations. Therefore, it is recommended to optimize grid size to get the required accuracy with efficient time for calculations. 
The grid independence test was conducted to verify the accuracy of the simulation. The process used one of the cladding building material and checking the temperature distribution along the external façade with multi-different number of cells.

The whole computational domain size will be $(4 \mathrm{~m} \times 6 \mathrm{~m}$ $\mathrm{x} 16 \mathrm{~m})$ and five different number of cells were considered through the study, they are $(57600,112500,123750,175500$ and 202500 cells $)$ with size of $(0.1667 \mathrm{~m} \times 0.2 \mathrm{~m} \times 0.2 \mathrm{~m}, 0.16 \mathrm{~m}$ x $0.133 \mathrm{~m} \times 0.16 \mathrm{~m}$, and $0.16 \mathrm{~m} \times 0.133 \mathrm{~m} \times 0.145 \mathrm{~m}, 0.1333 \mathrm{~m}$ x $0.1333 \mathrm{~m} \times 0.1231 \mathrm{~m}$, and $0.1333 \mathrm{~m} \times 0.1333 \mathrm{~m} \times 0.1067 \mathrm{~m}$ ) respectively. The results show the temperature distribution at the cells number (202500 and 175500) are more comparable with (123750 cells) with a difference of $3 \%$ in comparison to the domain of (57600 and 112500 cells) which is $10 \%$. Therefore, the researcher chose the optimum number of cells for the computational domain is 123750 cells as there is no significant change in the results when we use a large number of cells. Furthermore; the selection of large cells number will be a time consuming due to more running time and wasting resources due to the need for high-performance computers.

The general parameters of the simulation are described in Table 1.

Table 1. Parameters of simulation

\begin{tabular}{cccc}
\hline \multicolumn{4}{c}{ Parameters of simulation } \\
\hline $\begin{array}{c}\text { Number of } \\
\text { cells }\end{array}$ & Temperature & $\begin{array}{c}\text { Relative } \\
\text { humidity }\end{array}$ & $\begin{array}{c}\text { Simulation } \\
\text { time }\end{array}$ \\
123750 & $45^{\circ} \mathrm{C}$ & $25.0 \%$ & 600 seconds \\
\hline
\end{tabular}

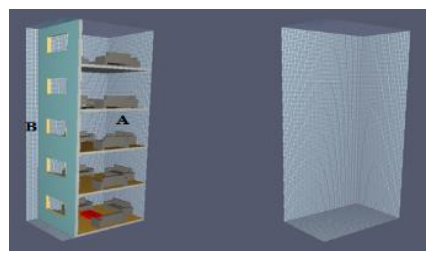

Figure 1. The computational domain

The computational domain shown in Figure 1 consists of two areas, where (A) represents the Enclosure (building with its furniture's) and (B) represents the open (External conditions) domain.

\section{GEOMETRIC CONFIGURATION AND CONTENTS OF THE SCENARIOS}

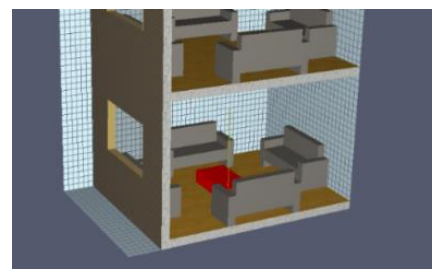

Figure 2. Contents of the scenario

The fire scenario consists of a five-story living space. Each story with one ( $3 \mathrm{~m} \mathrm{x} 1.2 \mathrm{~m}$ ) window. The story dimension is $(4 \mathrm{~m} \times 5 \mathrm{~m})$. Each floor is $3.2 \mathrm{~m}$ high and is separated by concrete floors (non-combustible material). The facade cladding material has changed as its the variable parameter of the study. Four sofas have used in each story and placed as shown in Figure 2.

- Upholstery (2mm Fabric and $10 \mathrm{~cm}$ Foam) used as default material for all sofas in this study.

- $20 \mathrm{~cm}$ Concrete block wall thick used as default material for the building construction walls.

- Gypsum used as a default finishing material for all interior walls.

- The Burner (fire source) is considered with constant (reference) HRRPUA of $1000 \mathrm{kw} / \mathrm{m}^{2}$ for generating the fire in this study.

\section{CLADDING AND FINISHING MATERIAL DETAILS}

The cladding and finishing materials that conducted in this study are Cement plastering, Limestone, perforated yellow brick and ACP-PE. The specifications of these materials used are described in Table 2 and Table 3.

\section{MEASUREMENT DEVICES}

Measuring devices were used through three slices places at the X-AXIS and there position is $(\mathrm{x}=1 \mathrm{~m}, 2 \mathrm{~m}$ and $3 \mathrm{~m}$ from the transverse edge of the model) each one of them for recording the temperature and air velocity in the computational domain for the whole running time of the study $(0-600 \mathrm{sec})$, as shown in Figure 3.

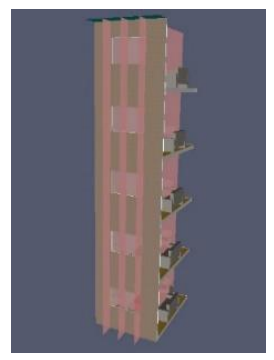

Figure 3. Measuring devices slices

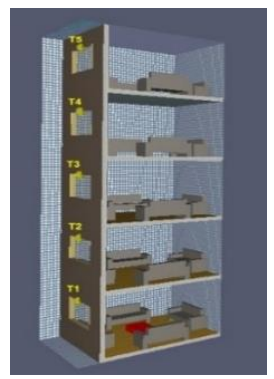

Figure 4. Locations of thermocouple

There are five more thermocouples placed in the middle of each story to measure the interior temperature change. The evolution data of the temperatures were only recorded through the five thermocouples in the middle slice located at the top edge of every story windows, which follow the main objective of the study that focuses on the leapfrog effects and it is distributed along the façade with different cladding materials (See Figure 4). Furthermore, two-dimensional chromatic planes in certain areas of the fire scenario were also used to observe the temperature distribution. 
Table 2. Cladding and finishing materials details

\begin{tabular}{ccccc}
\hline No. & Façade & Façade material & Thickness (mm) & Total Thickness (mm) \\
\hline $\mathbf{1}$ & ACP-PE & Aluminum & 0.5 & \\
& & Polyethylene & 3 & 124 \\
& & Aluminum & 0.5 & \\
& & Cavity & 100 & \\
$\mathbf{2}$ & & Cement Plastering & 20 & 20 \\
$\mathbf{3}$ & Cement plastering & Cement Plastering & 20 & 130 \\
& Limestone & Limestone & 100 & 145 \\
$\mathbf{4}$ & Perforated yellow brick & Cement-sand mortar & 30 & \\
& & Perforated yellow brick & 115 & \\
& & Cement-sand mortar & 30 & \\
\hline
\end{tabular}

Table 3. Sections and description in cladding and finishing materials

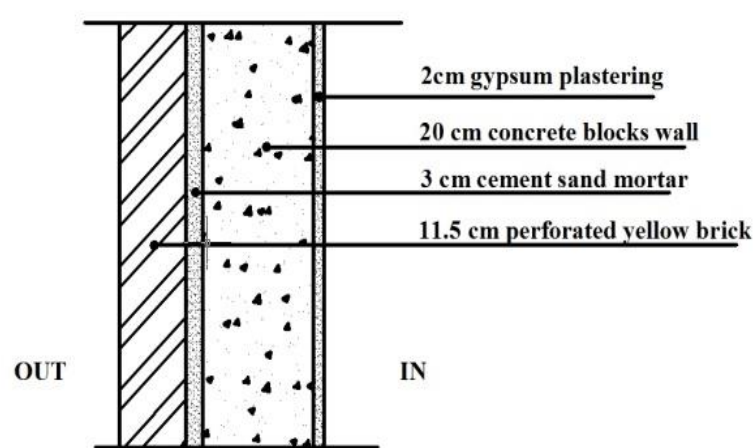

Perforated yellow brick

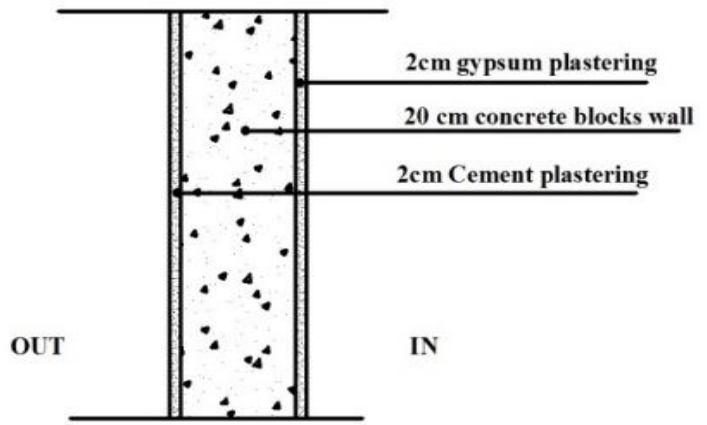

Cement plastering

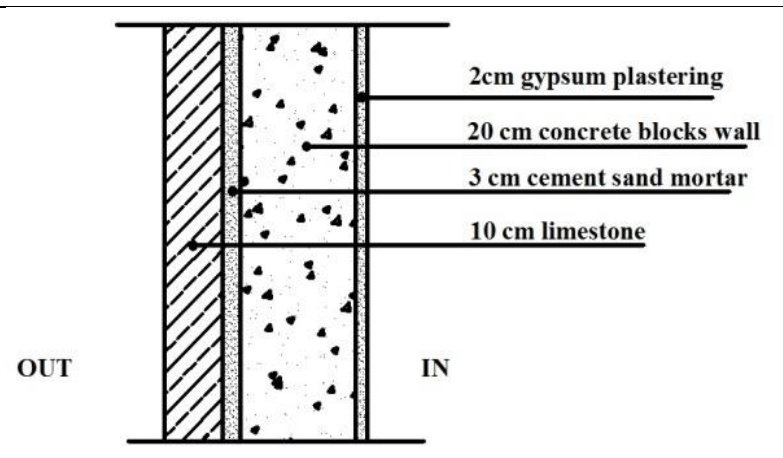

Limestone

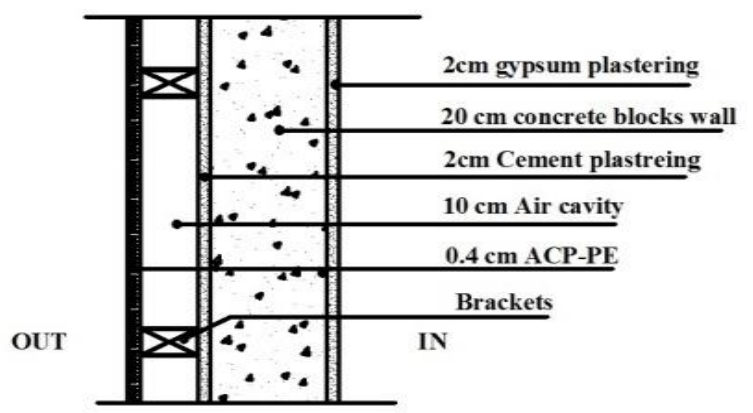

ACP-PE

\section{RESULTS}

To facilitate the comparison of the four finishing materials in terms of the performances against the spread of fire through the external facades, tables contains snapshots of tow dimensional chromatic planes of fire evolution have been taken every specific period $(100 \mathrm{sec}$.) for each of the four finishing material, and comparative charts of temperature have been conducted depending on five thermocouples.

The researcher suggested three time periods to base their snapshots upon, those periods were every $50 \mathrm{sec}$., $100 \mathrm{sec}$., and $150 \mathrm{sec}$. It found that using the $100 \mathrm{sec}$. The period is the most suitable, since having used the $50 \mathrm{sec}$. The time period did not show obvious differences in the fire propagation through the building facades between the chosen finishing materials and having used the $150 \mathrm{sec}$. The time period was too abbreviated and general.

\subsection{In the first 100 sec.}

The temperature distribution graphs at this time show that the fire is within the boundaries of a living room in the ground floor (the source of fire) and begins to spread, causing a rise in temperature within the internal space and trying to spread out to external facade. The speed of fire propagation and its impact are almost the same for all finishing materials, except the ACP-PE in which the space of the first floor begins to be affected slightly by the incidence of heat flux on façade surface as shown in Table 4 and Figure 5.

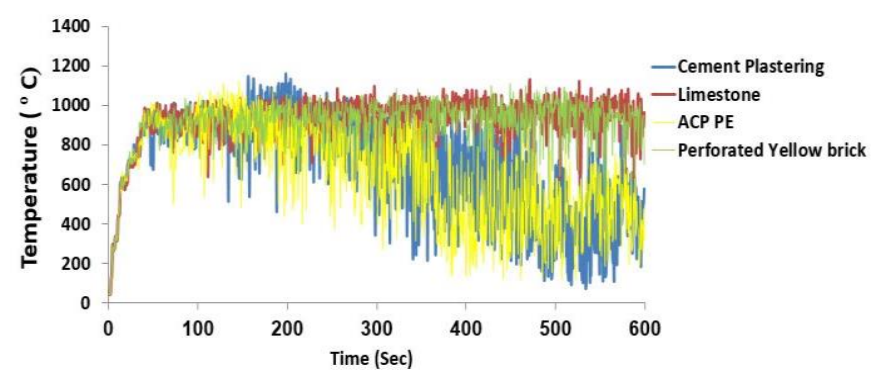

Figure 5. Comparative chart of temperature in thermocouple 1 
Table 4. The first $100 \mathrm{sec}$. of fire propagation scenario

The first 100 sec.

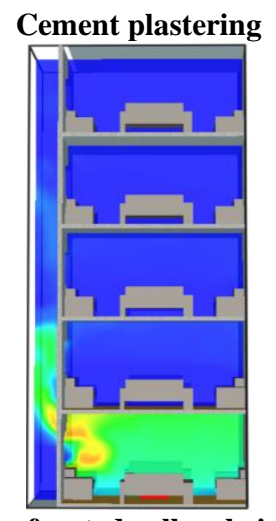

Perforated yellow brick

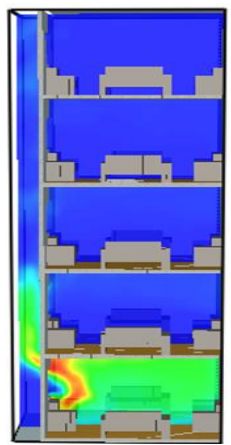

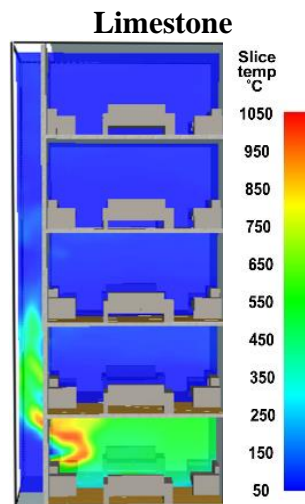

Aluminum Composite panels $-\mathbf{P E}$

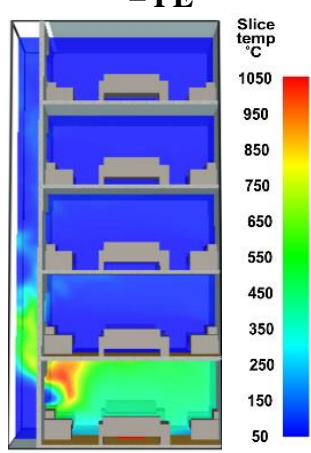

10.2 In the 200 sec.

The trajectory of Flames continues to spread and rise to upper floors so in case of:

Cement plastering: The fire has reached the first floor and the space of the first floor has started to affect by the heat flux without entering the fire, as for the effect of heat through the façade, it reaches the top of the second floor.

Limestone: The fire covered the wall of the first floor, which cause a rise in space temperature without entering the fire. The heat affects the external façade until the edge of the third floor.

Perforated yellow brick: Almost similar to the performances of the limestone façade.

ACP-PE: More fire spread through the façade reaching the middle of the third floor and begin to enter the first-floor space. As for the heat through the façade, it reaches the fourth floor and begins to affect the second and third-floor spaces.

In this stage, the ACP-PE considered the worst material against fire propagation. The perforated yellow brick is the best comparing with other finishing materials as shown in Table 5 and Figure 6.

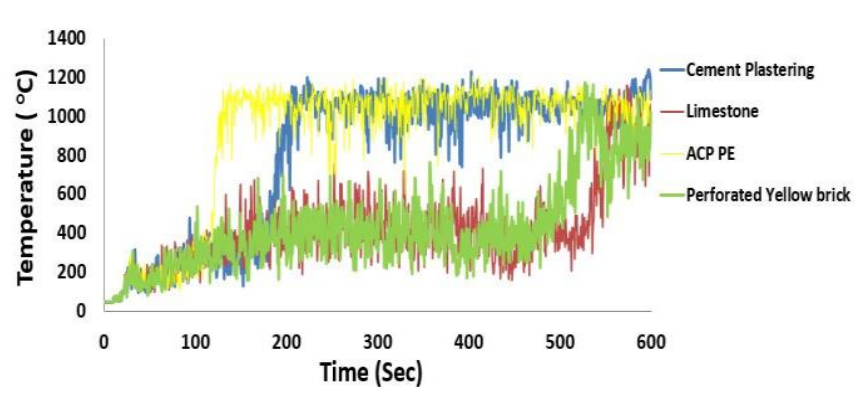

Figure 6. Comparative chart of temperature in thermocouple2
Table 5. The $200 \mathrm{sec}$. of fire propagation scenario

The 200 sec.

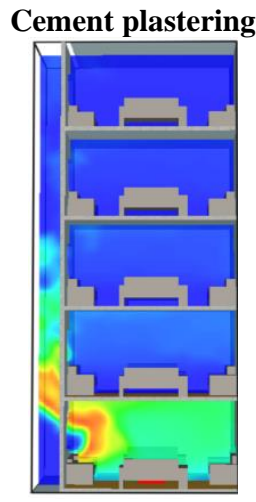

Perforated yellow brick
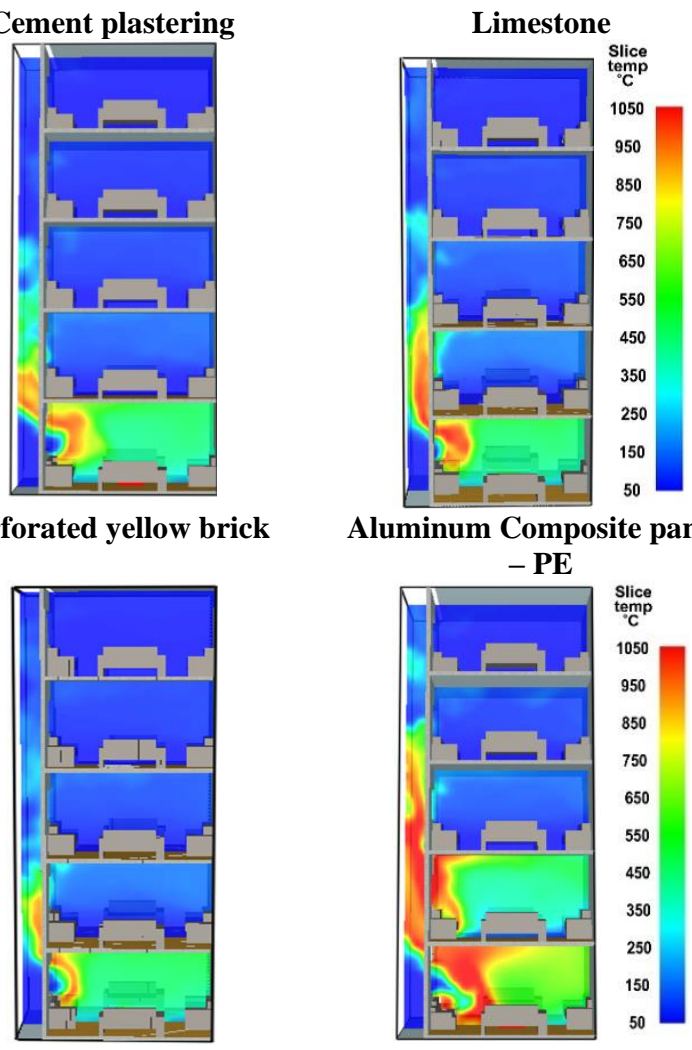

Aluminum Composite panels

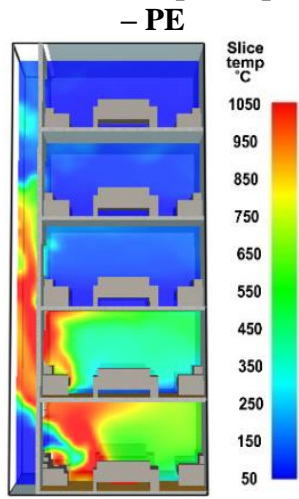

\subsection{In 300 sec.}

Cement plastering: The fire plume crosses the first-floor space causing an increase of the floor space temperature, the fire spread up to the end of second-floor façade. The heat through the façade reaches the fourth floor and begins to affect the second and third-floor spaces.

Limestone: The fire spread through the façade to the end of the first floor, and the first-floor space was affected by heat flux without entering the fire. The effect of heat through the façade reaches the edge of the third floor.

Perforated yellow brick: The fire through the facade reaches the middle of the first floor and the heat affect the third-floor external wall. An increase in temperature in the first-floor space without entering the fire.

ACP-PE: A very fast spread of fire through the façade that reaches the end of the fourth floor, i.e. covering the entire façade, the fire plume entering all the floors spaces causing an increase in their temperature.

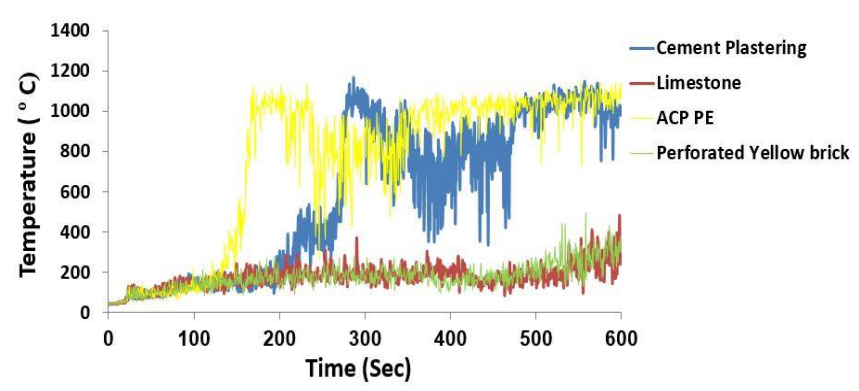

Figure 7. Comparative chart of temperature in thermocouple 3 
Table 6. The $300 \mathrm{sec}$. of fire propagation scenario

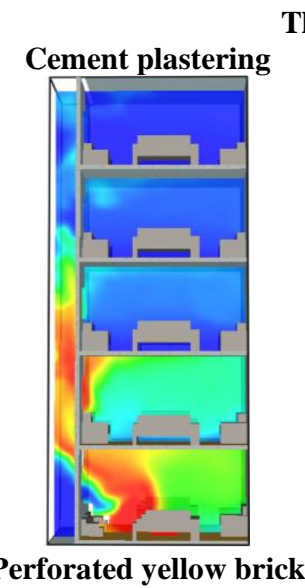

The 300 sec.

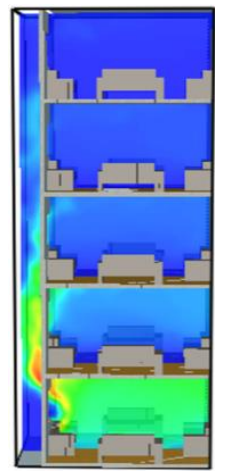

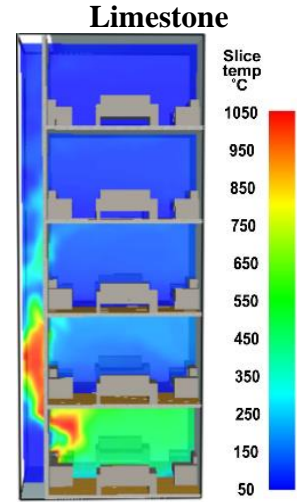

Aluminum Composite panels

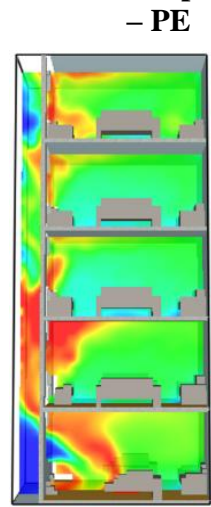

At this stage, also the ACP-PE is considered to be the worst material against fire propagation and the perforated yellow brick is the best, then the limestone and cement plastering. see Table 6 and Figure 7.

This is in line with the four-minute standard response time, that described in National Fire Protection Association [12]. The use of these two materials (yellow perforated brick and the limestone) for finishings of the external facades will allow firefighters to reach the fire site and extinguish it before the fire spreads to upper stories.

\subsection{In 400 sec.}

Cement plastering: A fast spread of fire through the façade that reaches the middle of the third floor and begins to enter the second-floor space. The third-floor space starts to affect by heat.

Limestone: The fire through the facade is still at the end of the first floor and there is an increase in temperature through the facade up to the edge of the fourth floor accompanied by an increase in temperature of the first-floor space without entering the fire.

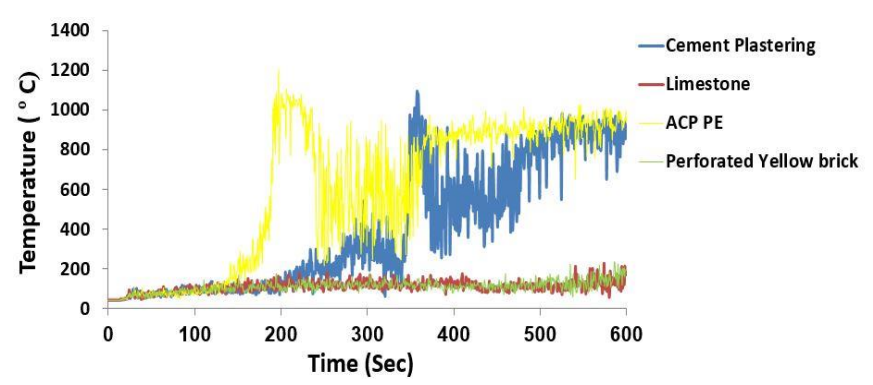

Figure 8. Comparative chart of temperature in thermocouple

Table 7. The $400 \mathrm{sec}$. of fire propagation scenario

The 400 sec.

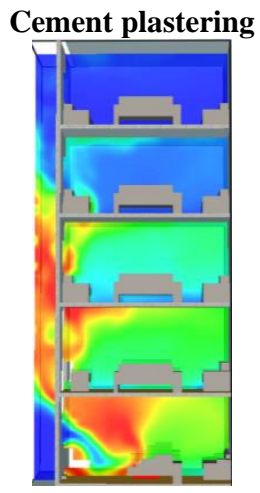

Perforated yellow brick
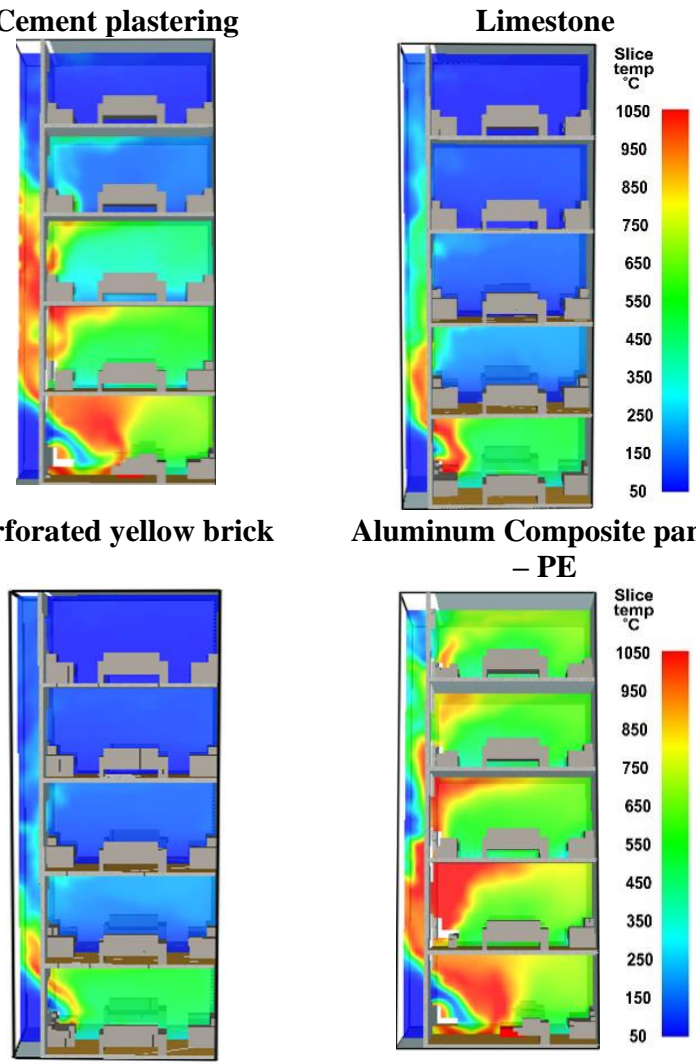

Aluminum Composite panels

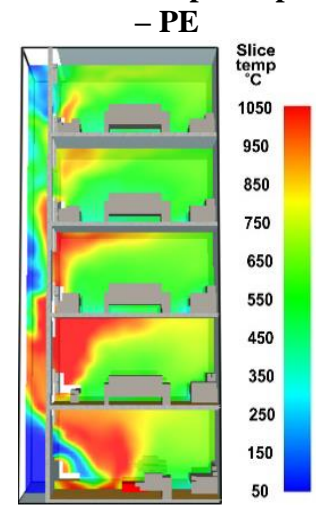

Perforated yellow brick: same situation as in (300 sec.) with minor changes.

ACP-PE: same situation as in (300 sec.) with an increase in temperature of the floors' spaces. See Table 7 and Figure 8.

\subsection{In 500 sec.}

Cement plastering: the fire covered the entire façade and entering all the floors' spaces with an increase in their temperature.

Limestone: same situation as in (400 sec.)

Perforated yellow brick: the fire through the façade reaches the top of the first floor and an increase of it is temperature without entering the fire

ACP-PE: An increase of fire intensity through the entire façade and entering to all floors' spaces. See Table 8 and Figure 9.

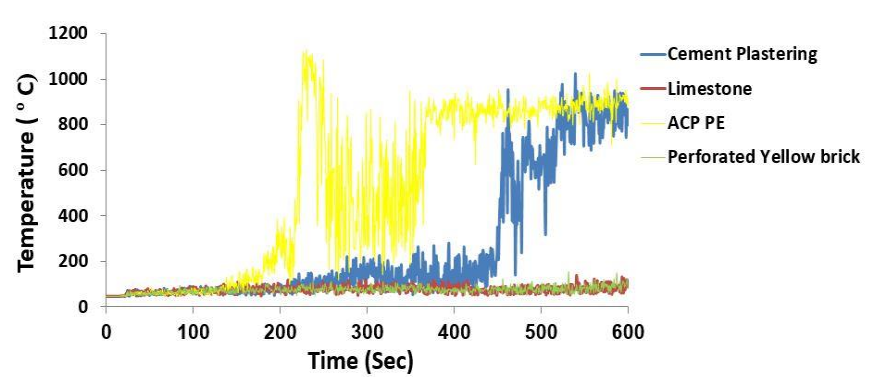

Figure 9. Comparative chart of temperature in thermocouple 5 
Table 8. The $500 \mathrm{sec}$. of the fire propagation scenario

\section{The 500 sec.}

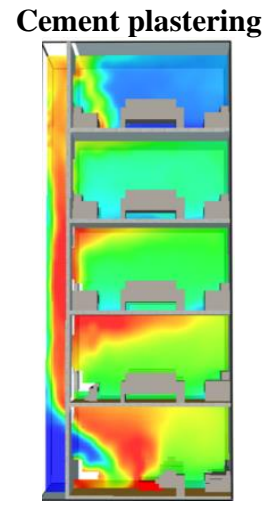

Perforated yellow brick

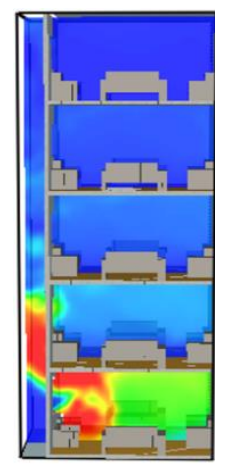

Limestone

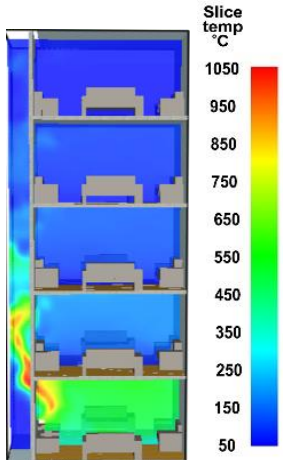

Aluminum Composite panels $-\mathbf{P E}$

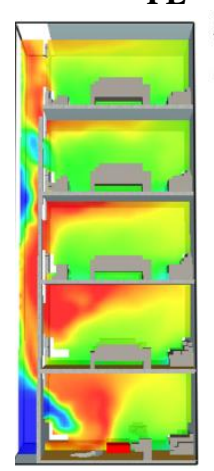

Table 9. The $600 \mathrm{sec}$. of fire propagation scenario

$$
\text { The } 600 \text { sec. }
$$

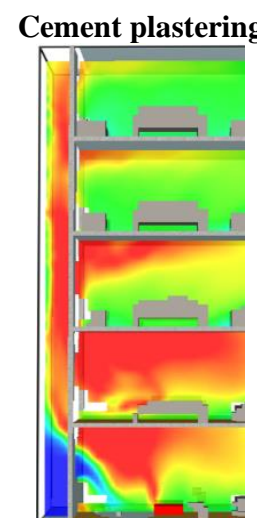

Perforated yellow brick

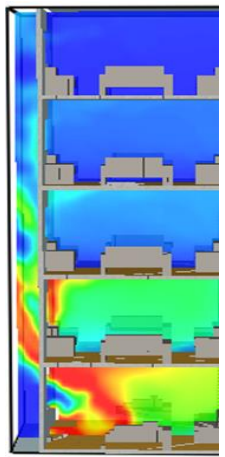

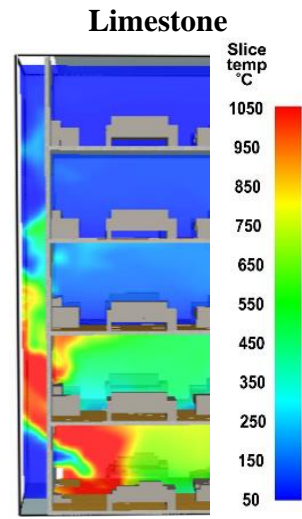

Aluminum Composite panels $-\mathbf{P E}$

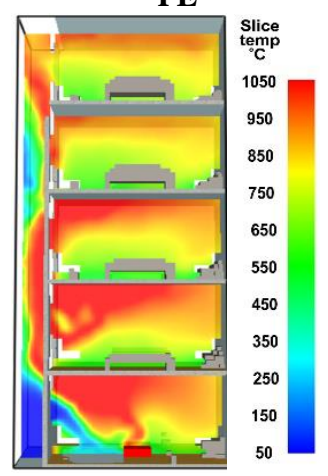

10.6 In 600 sec.

Cement plastering: An increase of fire intensity through the entire façade with an increase of all floors' spaces temperature

after spreading the fire into them.

Limestone: The fire through the façade reaches the middle of the second floor, and start to enter the first-floor space with a slight increase in temperature of the second floor.

Perforated yellow brick: The fire crosses the first-floor space through the façade and a slight increase in the temperature of the second-floor space.

ACP-PE: An increase of fire intensity through the entire façade and the floors' spaces. the third and fourth-floor facades start to collapse.

At this stage and the end of the simulation, the fire propagation through the façade was very speedy and horrible when using the ACP-PE as a cladding as shown in Table 9. This is proven by the real fires that occurred around the world, which used this combustible material as a cladding, such as the tragic fire of Grenfell Building in London in 2017, the fire originated on the fourth floor in this 24 stories residential building and it spread to the top floors within eight minutes. This led to a tragic loss of life, numerous injuries and total loss of the building, which was reportedly insured for (USD 26 million) [13].

\section{CONCLUSIONS AND RECOMMENDATIONS}

(1) The comparative study of the four finishing and cladding materials showed that there are obvious differences in the performances of each material against the spread of fire through building facades.

(2) The study showed the perforated yellow brick and limestone are similar in the performances against the spread of fire through the external facades. However, the brick showed slightly more efficient than the limestone. Therefore, the study recommends using it in facades finishing, especially in multistory buildings.

(3) The study highlighted that traditional finishing materials are more efficient than modern cladding materials and that the performance of ACP-PE is the worst among the materials examined by this study. Moreover, the cement plastering is the worst among the traditional local finishing materials.

(4) The study recommends the use of ACP-A2 and ACP-FR Aluminum composite panels that contain non-combustible materials in their cores, instead of ACP-PE panels especially in buildings that are more than 15 meters in height or the level that are not reached by the firefighting equipment.

(5) The study recommends the use of horizontal projection over windows with a certain width to deflect the trajectory of the flames outwards, preventing the incidence of heat flux on the facade surface according to the researches related to this field.

(6) The study recommends conducting more researches on other modern finishing materials that entering the Iraqi market to know its performance against fire propagation through the building façades.

\section{ACKNOWLEDGMENTS}

The researcher would like to acknowledge the University of Mosul, Engineering College, architectural department for the supporting to register of the current paper under the research plan in 2020. 


\section{REFERENCES}

[1] Al-Jawadi, M.H., Al-Tamimi, A.H. (2014). Thermal effect of external cladding materials on the miicroclimate in urban environment. Iraqi Journal of Architecture \& Planning, 13(1-2): 87-99.

[2] Saco, Z.M., Levon, A. (1983). Building Cnstruction. Mosul Iraq: Dar Elkotob Press for Printing and Publishing, University of Mosul.

[3] Guillaume, E., Fateh, T., Schillinger, R., Chiv, A., Ukleja, S. (2018). Study of fire behavior of façade mock-up equipped with aluminum composite material-based claddings, using intermediate-scale test method. Fire and Materials, $\quad 442(5)$ : $561-577$. https://doi.org/10.1002/fam.2635

[4] Agarwal, G. (2017). Evaluation of the fire performance of aluminum composite material (ACM) assemblies using ANSI/ FM 4880. MA. USA: FM Global.

[5] Giraldo, M., Diaz-Grande, A., Palacio, L., Vladimir, R. (2012). Computer-simulation research on buildingfacade geometry for fire spread control in buildings with wood claddings. Proceedings of the World Conference on Timber Engineering 2012, pp. 1-8.

[6] Oleszkiewicz, I. (1991). Vertical separation of windows using spandrel walls and horizontal projections. Fire Technology, 27: 334-340. https://doi.org/10.1007/BF01039884

[7] Mammoser, J.H., Battaglia, F. (2004). A computational study on the use of balconies to reduce flame spread in high rise apartment fires. Fire Safety Journal, 39(4): 278296. https://doi.org/10.1016/j.firesaf.2003.11.011

[8] White, N., Delichatsios, M. (2014). Fire hazards of exterior wall assemblies containing combustible components. Final Report. Massachusetts, USA: The Fire Protection Research Foundation.

[9] Palacio, L., Diaz-Grande, A., Forero, G., Leiva, B. (2013). Computer-simulation study on fire behaviour in the ventilated cavity of ventilated façade systems. MATEC Web of Conferences, pp. 03002-1-03002-11. https://doi.org/10.1051/matecconf/20130903002

[10] Yan, Z., Zhao, C., Liu, Y., Deng, X., Ceng, X., Liu, S., Lan, B., Nilsson, R., Jeansson, S. (2013). Experimental study and advanced CFD simulation of fire safety performance of building external wall insulation. MATEC Web of Conferences, 9: 1-10. https://doi.org/10.1051/matecconf/20130903005

[11] McGrattan, K., Hostikka, S., McDermott, R., Weinschenk, C., Forney, G. (2016). Fire Dynamics Simulator User's Guide. Special Publication (NIST SP) - 1019. https://doi.org/10.6028/NIST.sp.1019

[12] Esri, A. (2007). GIS for Fire Station Locations and Response Protocol. An ESRI White Paper.

[13] Bonner, M., Rein, G. (2018). Flammability and multiobjective performance of building façades: Towards optimum design. Int. J. High-Rise Build, 7: 363-374. https://doi.org/10.21022/IJHRB.2018.7.4.363 